\title{
ACTIVITY OF TRYPSIN-LIKE ENZYMES AND GELATINASES IN RATS WITH DOXORUBICIN CARDIOMYOPATHY
}

\author{
Iu. A. GORDIIENKO ${ }^{1}$, Ya. V. BABETS ${ }^{2}$, A. O. KULINICH ${ }^{1}$, \\ A. I. SHEVTSOVA ${ }^{1}$, G. O. USHAKOVA ${ }^{2}$ \\ ${ }^{1}$ SE Dnipropetrovsk Medical Academy of Health Ministry of Ukraine; \\ 'Oles' Honchar Dnipropetrovs'k National University, Ukraine; \\ e-mail: gordienko.ju@gmail.com
}

Activity of trypsin-like enzymes (ATLE) and gelatinases $A$ and $B$ were studied in the blood plasma and extracts from cardiac muscle, cerebral cortex and cerebellum of rats with cardiomyopathy caused by anthracycline antibiotic doxorubicin against the background of preventive application of corvitin and $\alpha$-ketoglutarate. ATLE significantly increased in blood plasma and extracts from cerebral cortex but decreased in extracts from cardiac muscle and cerebellum in doxorubicin cardiomyopathy (DCMP). In addition, a significant increase of activity of both gelatinases in plasma and tissue extracts was observed. Preventive administration of corvitin and $\alpha$-ketoglutarate resulted in differently directed changes of activity of the above mentioned enzymes in heart and brain tissues. Obtained data confirm the hypothesis about activation of proteolysis under the influence of anthracycline antibiotics and testify to selective effect of corvitin and $\alpha$-ketoglutarate on ATLE and gelatinases.

Key words: anthracycline antibiotics, cardiomyopathy, proteolysis, gelatinases A and B, trypsin-like enzymes, corvitin, $\alpha$-ketoglutarate.

I n physiological conditions, synthesis of proteins and their degradation are in dynamic equilibrium. This balance disturbance, due to excessive or inefficient degradation of intra- or extracellular proteins, causes many pathological states or may be their consequence [1]. Main regulators of these processes are proteolytic enzymes that may be divided into 5 classes by the mechanisms of their catalytic action: cysteine, serine, threonine, aspartate proteases and metalloproteinases. More than one third of known today proteinases are the serine ones and the most widespread among them are trypsin-like enzymes, which according to MEROPS classification belong to the S1 family in PA clan [2]. These enzymes play an important role in the processes of cell differentiation and migration, morpho- and angiogenesis, and in maintenance of homeostasis and immunity in mammals [3]. They are also key components of inflammatory reactions and remodeling of tissues in pathological states, including oncological and cardiovascular diseases. The mentioned pathologies are associated with degradation processes of extracellular matrix proteins under the impact of matrix metalloproteinases (MMP) - calcium dependent enzymes with similar domain organization that contain zinc in their active centre. Among three tens of already known MMP, the ones of special attention are gelatinases A (MMP2, EC 3.4.24.24) and B (MMP9, EC 3.4.24.35), which are considered to be key enzymes in development and dissemination of tumors [4], destruction of atherosclerotic plaque and post-infarction remodeling of the cardiac muscle [5]. However, the data about activity of these enzymes in development of the above mentioned pathologies are rather contradictory.

In modern oncotherapy, anthracycline antibiotics (AA) are widely used as effective antitumor agents. However, these compounds may reveal both therapeutic effect, ensuring destruction of malignant clone, and powerful damaging action on normal cells. Negative influence of AA on the organism during antitumor therapy and/or after its completion shows itself as a series of side effects, which require lowering of the drugs dose or stop the treatment. Most frequent complication after AA application is nonrecoverable heart affection, which results in inadequate myocardium contractile function and further development of cardiomyopathy. Negative effect of AA is not restricted only to destructive action on the myocardium. No less important compli- 
cation is neurotoxic action of these compounds, in spite of the knowledge that these drugs cannot penetrate through blood brain barrier [6]. Nowadays, there are no standards of treating the complications of AA chemotherapy; therefore, the question how to diminish toxicity of these drugs without considerable lowering of their antitumor action is still actual. Antioxidant compounds of natural origin that exert no harmful effect on the patient organism may be considered as such therapeutic and preventive substances. They include corvitin (water-soluble form of bioflavonoid quercetin) and $\alpha$-ketoglutarate $(\alpha K G)-$ a metabolite of the tricarboxylic acid cycle. The former one possesses antioxidant activity, while the other is the compounds which action is directed at optimization of cell energy metabolism. It is also known that $\alpha \mathrm{KG}$ may act as detoxicant of active forms of oxygen and ammonia; that is, it may be attributed to antioxidants. However, it is unknown how these drugs influence the activity of proteolysis in the heart and brain tissues with AA application. With regard to the above-said, it is a matter of topical interest to investigate activity of proteolytic enzymes in blood plasma, cardiac muscle and different parts of brain under doxorubicin cardiomyopathy (DCMP) and corvitin and $\alpha \mathrm{KG}$ application.

\section{Materials and Methods}

Experimental studies were performed on male rats of Wistar line with weight of $210 \pm 50 \mathrm{~g}$. The animals were divided into 4 groups, 8 rats in each one, and were maintained in standard conditions of animal house. In all groups, besides the control one, the model of doxorubicin cardiomyopathy (DCMP) was used: anthracycline antibiotic doxorubicin (Doxorubicin-KMP, Open stock Corporation "Kyivmedpreparat", Ukraine) was administered to the rats intraperitoneally every week during 28 days in dose $1 \mathrm{mg}$ per $\mathrm{kg}$ of weight [7]. Animal of the first group (control) were injected with physiological solution; animals with DCMP were in the second group; the third one included the rats that were injected intraperitoneally by corvitin (Borshchahivskiy ChemicalPharmaceutical Plant, Ukraine) in dose $5 \mathrm{mg}$ per kg of weight (30-60 minutes before doxorubicin injection); the animals of the fourth group were injected with doxorubicin and supported during all experiment by $1 \% \alpha$-ketoglutarate in drinking water $(0.5 \%$ $\mathrm{Ca}-\alpha \mathrm{KG}+0.5 \% \mathrm{Na}-\alpha \mathrm{KG}$, Splus, Sweden) that was courteously given by prof. S. Pierzynowsky. Animals of the last group received daily on the average
$43 \mathrm{ml}$ of drinking water per $1 \mathrm{~kg}$ of weight. At the end of the experiment, the animals were decapitated under sodium thiopental $(60 \mu \mathrm{g} / \mathrm{kg})$ according to the principles of European Convention for the Protection of Vertebrate Animals used for Experimental and other Scientific Purposes. The citrated plasma, heart and brain of the experimental animals were used for research.

Tissue extracts of heart and different parts of brain were obtained by their homogenization in $0.025 \mathrm{M}$ tris- $\mathrm{HCl}$ buffer ( $\mathrm{pH}$ 7.2) in the ratio 1:4 with further centrifugation at $2860 \mathrm{~g}$ during $5 \mathrm{~min}$ at $4{ }^{\circ} \mathrm{C}$; the supernatants were sampled for further experiments.

To determine activity of trypsin-like enzymes (ATLE), the microvariant of Veremeienko method was used [8]. It is based on cleavage N-benzoyl-D-Larginine-4-para-nitroanilide hydrochloride (Sigma, USA) by these enzymes with formation of para-nitroaniline, which colouring level was registered by a photometer (Human $\mathrm{GmbH}$, Germany) at $410 \mathrm{~nm}$. For quantitative evaluation, different dilutions of trypsin (Sigma) were used as standart solutions; ATLE was calculated in International units (IU/ml).

Activities of gelatinases A and B (MMP2 and MMP9, correspondingly) were determined by the method of direct enzyme-zymography after vertical electrophoresis of samples in 7.5\% PAG containing $0.1 \%$ SDS and $1 \%$ gelatine (Sigma). Gelatinases in zymograms were revealed as transparent lysis strips on a blue background. The lysis zones of MMP2 and MMP9 were distinguished with the use of markers Bio-Rad Lab (USA) and positive control on these enzymes (Sigma). On the following step, zymograms were converted into digital format and gelatinase activity was calculated with the program Videodensitometer Sorbfil 2.0. Gelatinase activity was determined in arbitrary units (arb. units) relative to their activities in a standard sample, where their activity has been taken for 1 arb. unit. Blood plasma pools and extracts of cardiac muscle, cerebral cortex, and cerebellum, taken from the control rat group, were used as standard: equal volumes of plasma or respective tissue extracts were mixed together [9]. Protein concentrations in plasma and extracts of the heart and brain tissues were determined by Bradford method [10]. Specific activity of studied enzymes was calculated per $1 \mathrm{mg}$ of protein.

Statistical estimation of results obtained was performed with programs Statwin and Excel, using Student $t$-test and nonparametric Mann-Whitney 
test (U-test). Results were assumed significant at $P \leq 0.05$.

\section{Results and Discussion}

The development of cardiomyopathy in studied animals was demonstrated by morphometric and histochemical analysis. Experimental animals with doxorubicin application had a decreased heart mass index. Simultaneously, the increased heart shape index was established, which evidenced for changing from ellipsoid to spherical heart form. Histological data testified to different levels of cardiomyocyte dystrophic changes, presence of diffuse cardiosclerosis and hemorrhages. Activity of the basic cardiac specific enzymes (aspartate aminotransferase, lactate dehydrogenase and MB-form of creatine kinase) were increased also [11].

The table below presents the data of ATLE in analyzed samples. It can be noted that activity of trypsin-like enzymes in plasma rats of the $2^{\text {nd }}$ group is increased three times, while the level of total protein is lowered. Application of corvitin or $\alpha \mathrm{KG}$ did not prevent such changes: the ATLE level remained high on the background of decreased total protein. Ratio ATLE/total protein proved to be more indicative. Our data shown that this coefficient in plasma of rats with doxorubicin induced cardiomyopathy increased 3-4 times, as compared to normal values, and remained high in spite of preventive therapy with compounds of mentioned above. Different ratio ATLE/total protein was observed in cardiac muscle extract: for rats with DCMP this index was significantly decreased, but under corvitin or $\alpha \mathrm{KG}$ application it was increased, however, did not achieve the normal values.

Differently directed ATLE changes in plasma and cardiac muscle may be accounted by their different origin and different activation levels of proper enzymes. Main ATLE enzymes in plasma are blood coagulation factors (thrombin, Xa factor) and fibrinolysis system (plasmin), which activity increases (directly or indirectly) with application of anthracycline antibiotics [12]. Additional contribution to ATLE increase in blood is its production by leukocytes and macrophages. It is well known that activation of these cells at inflammatory process, associated with cardiomyopathy, leads to release of tryptases, granzymes and other trypsin-like enzymes with their entering into bloodstream [13]. Significant ATLE lowering in cardiac muscle extract of DCMP group may be result of disordered cardio- myocyte membrane permeability under doxorubicin; its renewal with corvitin application indicates that these compounds may stabilize cell membranes. The increase of ATLE level in the $4^{\text {th }}$ group rats, which were given $\alpha \mathrm{KG}$ with drinking water may be explained by oxygen sensitive regulation of gene expression under the influence of hypoxia-inducible factor (HIF). Increased level of oxygen leads to the inhibition of HIF due to its degradation by the ubiquitin ligase that recognizes hydroxyproline and hydroxylysine in this factor. Posttranslational hydroxylation proline or asparagine in regulatory subunit of HIF and other proteins is provided by 2-oxoglutarate dependent dioxygenases that use $\alpha \mathrm{KG}$ as the co-substrate [14]. It may be supposed that $\alpha \mathrm{KG}$ application not only increases energy support of myocardium cells but influences indirectly the functioning of ubiquitin proteasome system, which components display trypsin-like activity.

The analysis of ATLE levels in different parts of brain showed that the ratio ATLE/total protein is 2.3 times increased in cortex extract, while in cerebellum this index was 1.2 times decreased compared to the control group. Preventive application of corvitin or $\alpha \mathrm{KG}$ differently influenced on this index: corvitin increased it in both parts of brain, while $\alpha \mathrm{KG}$ led to its decrease (Table). Earlier, neuroprotective effect of oral administration of $\alpha \mathrm{KG}$ under the conditions of cyanide induced biochemical changes in the rat brain was shown by Tulsawani et al. [15]. Our previous results indicated also that $\alpha$ KG may prevent nerve cell damage, which takes place under experimental ischemia of brain [16].

Our experimental data of gelatinases A and B activity in blood plasma and cardiac muscle extracts is shown at Fig. 1. The activity of both latent and mature forms of gelatinases A and B in plasma was increased under condition of DCMP. Relative activity of proMMP9 was especially high -1.8 times increased. Application of corvitin led to renewal of the initial level of MMP9 activity and to lowering proMMP9 activity, however, the level of the latter remained significantly increased as compared to the control group. Other changes of gelatinase B activity in blood plasma were observed under influence of $\alpha \mathrm{KG}$ : proMMP9 activity was decreased while the activity of MMP9 was increased as compared to the DCMP group. Concerning gelatinase A, both corvitin and $\alpha K G$ applications resulted in increasing activity of both forms of this enzyme in blood plasma (Fig. 1, A). 
Activity of trypsin-like enzymes (ATLE) in blood plasma, cardiac muscle and different parts of brain in rats with doxorubicin cardiomyopathy (DCMP)

\begin{tabular}{|c|c|c|c|c|}
\hline Significants & $\begin{array}{l}1^{\text {st }} \text { group, } \\
\text { control }\end{array}$ & $2^{\text {nd }}$ group, DCMP & $\begin{array}{l}3^{\text {rd }} \text { group, DCMP } \\
+ \text { corvitin }\end{array}$ & $\begin{array}{l}4^{\text {th }} \text { group, DCMP } \\
+\alpha \text {-ketoglutarate }\end{array}$ \\
\hline \multicolumn{5}{|c|}{ Blood plasma } \\
\hline ATLE, IU/ml & $0.083 \pm 0.016$ & $0.246 \pm 0.036^{* * *}$ & $0.237 \pm 0.050^{* * *}$ & $0.262 \pm 0.044^{* * *}$ \\
\hline Total protein, mg/ml & $59.90 \pm 1.28$ & $55.43 \pm 2.04$ & $48.30 \pm 2.32^{* * * / \S}$ & $47.13 \pm 3.14^{* * / \S}$ \\
\hline ATLE/total protein, IU/mg & $0.0014 \pm 0.0003$ & $0.0044 \pm 0.0008 * *$ & $0.0049 \pm 0.0011^{* *}$ & $0.0056 \pm 0.0020^{*}$ \\
\hline \multicolumn{5}{|c|}{ Cardiac muscle extract } \\
\hline ATLE, IU/ml & $1.397 \pm 0.126$ & $0.679 \pm 0.038^{* * *}$ & $1.133 \pm 0.062^{\S \S \S}$ & $0.893 \pm 0,053^{* * / \$ \S}$ \\
\hline Total protein, mg/ml & $7.43 \pm 0.91$ & $8.72 \pm 0.87$ & $10.02 \pm 0.30 *$ & $8.08 \pm 1.01$ \\
\hline ATLE/total protein, IU/mg & $0.188 \pm 0.025$ & $0.078 \pm 0.009^{* * *}$ & $0.113 \pm 0.065$ & $0.111 \pm 0.024^{*}$ \\
\hline \multicolumn{5}{|c|}{ Brain cortex extract } \\
\hline ATLE, IU/ml & $0.242 \pm 0.038$ & $0.614 \pm 0.089 * *$ & $0.535 \pm 0.049^{* * *}$ & $0.437 \pm 0.025^{* * *}$ \\
\hline Total protein, mg/ml & $1.95 \pm 0.25$ & $2.10 \pm 0.18$ & $1.71 \pm 0.11$ & $2.11 \pm 0.34$ \\
\hline ATLE/total protein, IU/mg & $0.124 \pm 0.004$ & $0.292 \pm 0.026^{* * *}$ & $0.313 \pm 0.013^{* * *}$ & $0.207 \pm 0.031 *$ \\
\hline \multicolumn{5}{|c|}{ Cerebellum extract } \\
\hline ATLE, IU/ml & $0.395 \pm 0.039$ & $0.230 \pm 0.040 *$ & $0.398 \pm 0.022^{\S \S}$ & $0.274 \pm 0.026^{*}$ \\
\hline Total protein, mg/ml & $2.51 \pm 0.16$ & $1.86 \pm 0.12^{* *}$ & $1.99 \pm 0.16$ & $2.34 \pm 0.18^{\S}$ \\
\hline ATLE/total protein, IU/mg & $0.157 \pm 0.012$ & $0.124 \pm 0.035$ & $0.200 \pm 0.028$ & $0.117 \pm 0.015$ \\
\hline
\end{tabular}

Note: $* P \leq 0.05,{ }^{* *} P \leq 0.01,{ }^{* * *} P \leq 0.001$ - significant value compared to control group; ${ }^{\S} P \leq 0.05,{ }^{\S \S} P \leq 0.01$, ${ }^{\S \S} P \leq 0.001$ - significant difference compared to DCMP group.
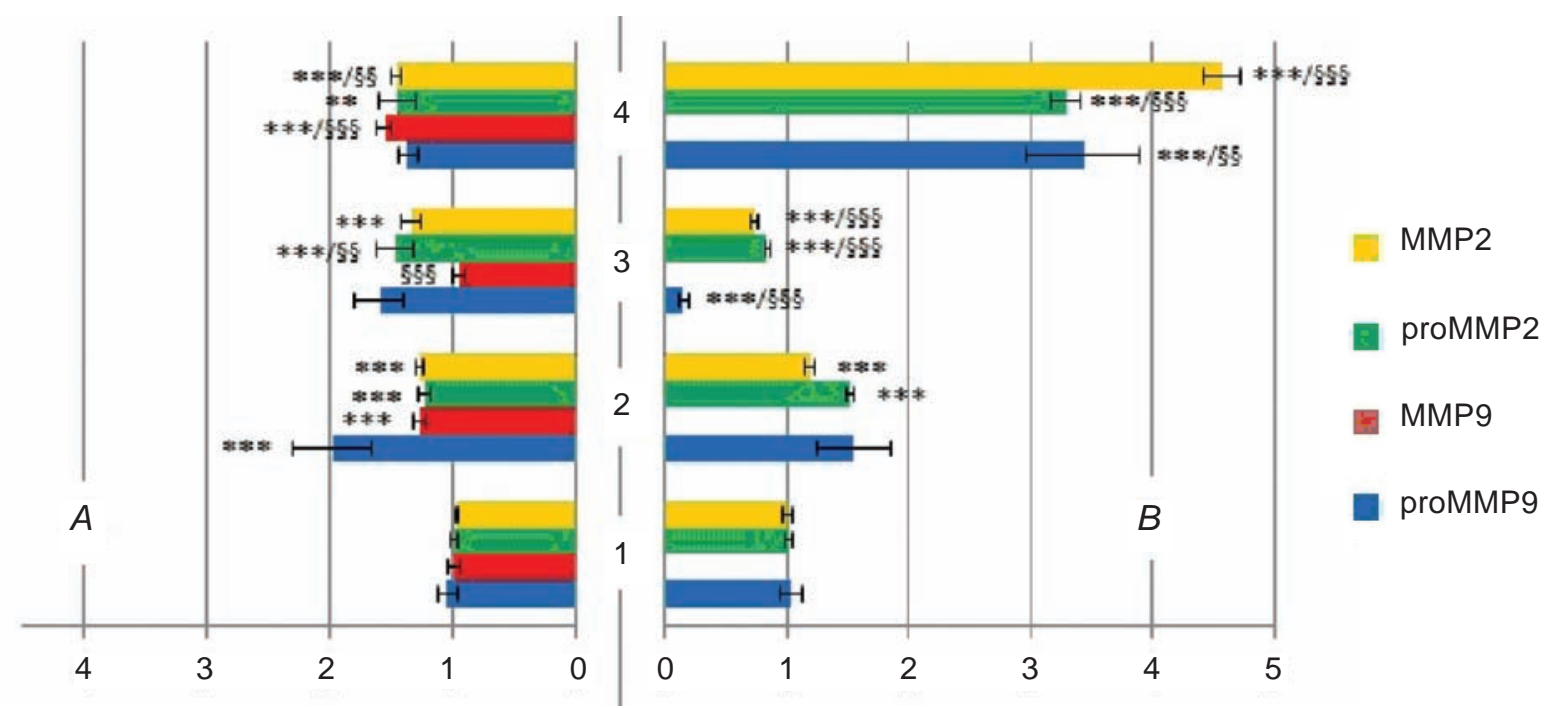

Fig. 1. Relative activity of MMP2 and MMP9 (arb. units/mg of protein) in blood plasma (A) and cardiac muscle extract $(B)$ under doxorubicin cardiomyopathy $(D C M P): 1-$ control, $2-D C M P, 3-D C M P+$ corvitin, $4-D C M P+\alpha$-ketoglutarate. $* P \leq 0.05, * * P \leq 0.01$, *** $P \leq 0.001$ - significant value compared to control group; ${ }^{\S} P \leq 0.05,{ }^{\S \S} P \leq 0.01,{ }^{\S \S \S} P \leq 0.001$ - significant difference compared to DCMP group 
We also observed the increase of gelatinase activity in the cardiac muscle under DCMP, with the exception of MMP9 that was not revealed in any sample due to extraction protocol and further gelatin zymography. Under corvitin effect, the activity of both gelatinases decreased and was significantly below normal values, whereas the $\alpha \mathrm{KG}$ effect was accompanied by the considerably increased activity of these enzymes (Fig. 1, B).

Increasing activity of gelatinases in the plasma and cardiac muscle of experimental animals under DCMP may be the result of enhanced synthesis or activation of these enzymes with the participation of free radical forms of oxygen (ROS), which appear under doxorubicin effect. According to Mukhopadhyay et al. [17], doxorubicin application leads to the increase of gene expression of MMP2, MMP9 and inducible NO-synthase in rat cardiomyocytes. These authors established the increased production of active forms of oxygen also, including peroxynitrite, which has the most powerful damaging effect on cardiomyocytes [17]. High concentrations of peroxynitrite lead not only to contractile disfunction of myocardium due to tyrosine nitration in actomyosin complex, but also to nonproteolytic activation of MMPs. Peroxynitrite takes part in joining glutathione to SH-group of cysteine in propeptide domain of MMP2; that leads to exposing active center of the enzyme, degradation of sarcomere proteins and damage of cardiomyocyte structure and function. An analogous mechanism of nonproteolytic activation of proenzyme forms was also found in other MMP, including MMP9. Inactivation of tissue inhibitor of metalloproteinases 4 (TIMP4) by peroxynitrite is additional contribution to increasing activity of gelatinases under doxorubicin [18].

Low activity of both gelatinases in the cardiac muscle with application of corvitin may be accounted by the ability of bioflavonoid quercetin (main component of this drug) to inhibit ROS formation and lipid peroxidation (LPO) at different stages, to decrease MMP expression and increase synthesis of tissue inhibitor of metalloproteinases 1 (TIMP1). Quercetin inhibits also the synthesis of factor NF- $\kappa B$, which leads to low level of pro-inflammatory cytokine TNF- $\alpha$ and, indirectly, to low gelatinases activity [19]. It was recently shown that quercetin may decrease the expression of gelatinases in coronary vessels through inhibition of JNK/AP-1 signaling pathway [20].

The substantial increase of gelatinase activity in the cardiac muscle under $\alpha \mathrm{KG}$ application is difficult to explain by its influence on energy metabolism in myocardium. This unexpected reaction may be caused most likely by some compositional features of the compound used in our experiment, which contained calcium and sodium salts of $\alpha \mathrm{KG}$. It is known that MMPs are calcium dependent enzymes, and calcium ions are strong activators of these enzymes both in vivo and in vitro; that is why $\mathrm{Ca}^{2+}$ is one of the compounds of incubation buffer due to performing gelatin zymography. Therefore, long use of $\mathrm{Ca}^{2+}-\alpha \mathrm{KG}$ with drinking water might lead to paradoxical increase of gelatinase activities.

Gelatinases participate in different neuronal processes: neuron differentiation, astrocyte migration, angiogenesis and ensuring synaptic plasticity. In normal state, brain gelatinases are supposed to be in latent form. The expression and activation of these enzymes became increased at ischemia, traumatic injury of brain and also at neurodegenerative states of different origin [21]; however, the reaction of neural tissue to therapeutic doses of anthracycline antibiotics is not practically determined.

Our results showed the significant increase of proMMP9 and MMP9 activities (2.54 \pm 0.14 and $1.76 \pm 0.10$ arb. units, accordingly) in brain cortex extract under DCMP. Activity of gelatinases was increased also in rat cerebellum extract under DCMP, except for MMP9; its activity was not revealed in this part of brain in our experiment. It is known that under normal state insignificant expression of both gelatinases takes place in cerebellum. In experiment on the culture of isolated rat neurons, Lopes et al. showed that low doses of doxorubicin $(0.5 \mu \mathrm{M})$ resulted in cell apoptosis, while higher doses of this anthracycline antibiotic led to cell necrosis. The authors connect doxorubicin neurotoxicity with activation of neuronal NO-synthase, free-radical oxidation and NF- $\kappa B$ [22]. Therefore, the increase of gelatinase activity in brain of rats with DCMP may be explained by involvement of the same processes as in the cardiac muscle. Note that ability of anthracycline antibiotics, including doxorubicin, to penetrate through blood brain barrier is limited [23]; however, gelatinase activation leads to destruction of this barrier due to proteolysis of main proteins [24].

Unexpected results were obtained during studying corvitin and $\alpha \mathrm{KG}$ effect to gelatinase activity in different parts of brain. Preventive application of corvitin resulted to lowering proMMP activity in the extract from brain cortex to practically normal values (1.21 \pm 0.05 arb. unites), whereas MMP9 and 

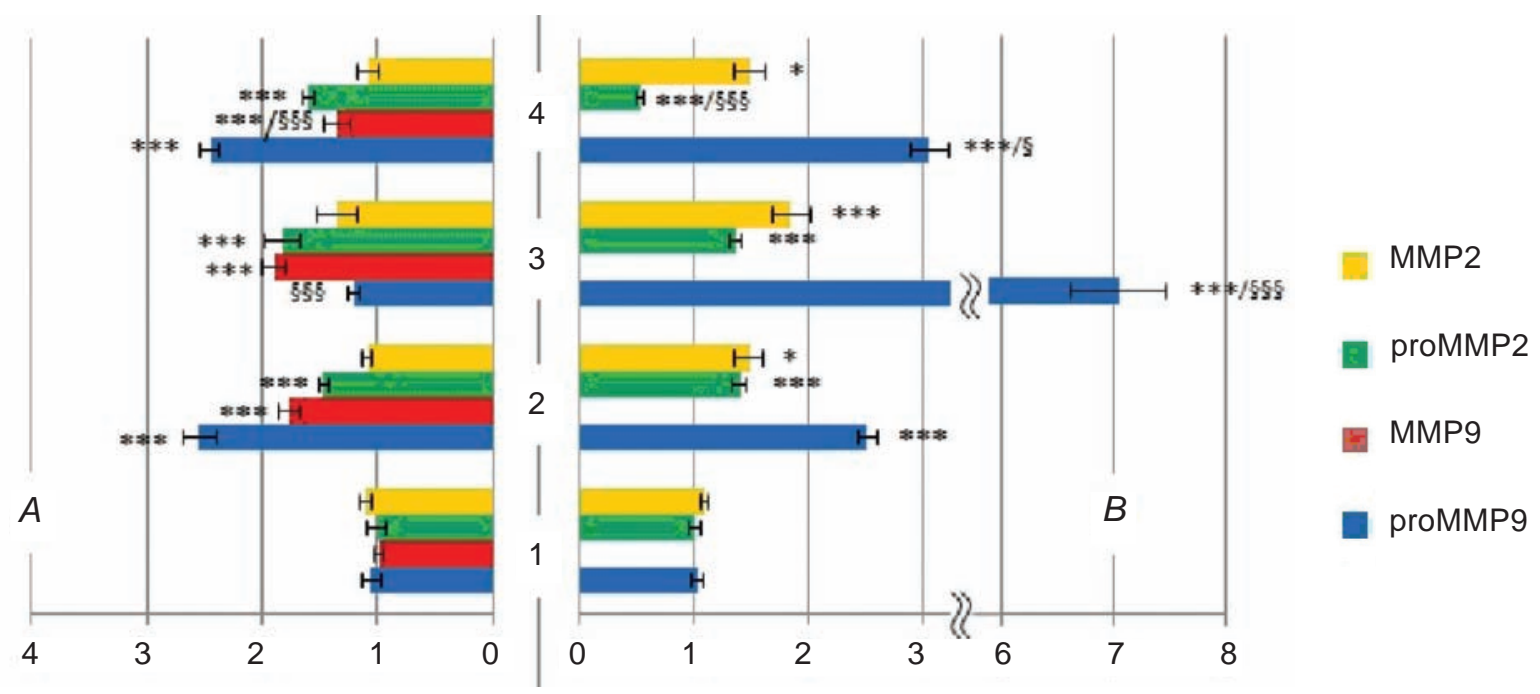

Fig. 2. Relative activity of MMP2 and MMP9 (arb. units/mg of protein) in extracts from brain cortex (A) and cerebellum (B) under doxorubicin cardiomyopathy (DCMP): 1-control, $2-D C M P, 3-D C M P+$ corvitin, $4-D C M P+\alpha$-ketoglutarate. ${ }^{*} P \leq 0.05, * * P \leq 0.01, * * * P \leq 0.001$ - significant value compared to the control group; ${ }^{\S} P \leq 0.05,{ }^{\S \S} P \leq 0.01,{ }^{\$ \S \S} P \leq 0.001$ - significant difference compared to DCMP group

MMP2 activities increased twice compared to the normal state. Differently directed changes of gelatinase activity in this part of brain were observed with $\alpha \mathrm{KG}$ application: activity of their latent forms was increased, while, on the contrary, activities of the proteolytically active forms were decreased compared to rats with DCMP (Fig. 2, $A$ ). Other changes of gelatinase activity were observed in cerebellum: under the effect of both compounds the activity of proMMP9 significantly increased compared to this index in DCMP rats, whereas proMMP2 activity did not change with corvitin application, but decreased 2.8 times with the use of $\alpha \mathrm{KG}$ (Fig. 2, B). Our data differ from results of other researchers, who purpose that quercetin displays neuroprotective action through inhibition of MMP9 activity in the ischemic brain [25]. It should be noted that ability of biologically active flavonoids to penetrate through blood brain barrier is mediated by P-glycoprotein and decreases with the increase of hydroxyl and glycoside groups in their structure. Quercetin contains five hydroxyl groups that restrict its entering to brain. Quercetin transport was shown to increase when inhibiting P-glycoprotein with verapamil application [26].

Obtained data allow us to make the following summary. Application of doxorubicin leads to considerable increase of proteolytic activity of trypsinlike enzymes and gelatinases in blood, cardiac muscle and brain tissues. Differently oriented changes of the MMPs and ATLE are observed under the application of corvitin and $\alpha$-ketoglutarat, which indicates different sensitivity of the heart and brain cells to these compounds and different mechanisms of their effect on intracellular proteolytic enzymes and matrix proteinases.

\section{АКТИВНІСТЬ ТРИПСИНОПОДІБНИХ ЕНЗИМІВ ТА ЖЕЛАТИНАЗ У ЩУРІВ ІЗ ДОКСОРУБІЦИНОВОЮ КАРДІОМІОПАТІЕЮ}

\author{
Ю. А. Гордієнко ${ }^{1}$ Я. В. Бабеиьь ${ }^{2}$, \\ А. О. Кулініч ${ }^{1}$, А. І. Шевцуова 1 , Г. О. Уиакова \\ ${ }^{1}$ Д3 «Дніпропетровська медична \\ академія MO3 України»; \\ ${ }^{2}$ Дніпропетровський національний \\ університет імені Олеся Гончара,Україна; \\ e-mail: gordienko.ju@gmail.com
}

Проведено дослідження активності трипсиноподібних ензимів (АТПЕ) та желатиназ А і В у плазмі крові, в екстрактах серцевого м'яза, кори головного мозку та мозочка щурів 3 кардіоміопатією, спричиненою антрацикліновим антибіотиком доксорубіцином на фоні превентивного застосування корвітину та $\alpha$-кетоглутарату. Показано, що АТПЕ вірогідно збільшується у плазмі крові та екстракті кори головного мозку за доксорубіцинової кардіоміопатії (ДКМП), а в екстрактах серцево- 
го м'яза та мозочка - знижується. За умов ДКМП відбувається вірогідне підвищення активності обох желатиназ у плазмі та тканинних екстрактах. Превентивне введення корвітину i $\alpha$-кетоглутарату спричинює різноспрямовані зміни активності означених ензимів у тканинах серця та мозку. Одержані дані підтверджують гіпотезу про активацію протеолізу за дії антрациклінових антибіотиків і свідчать про вибірковість впливу корвітину і $\alpha$-кетоглутарату на АТПЕ та желатинази.

Ключові слова: антрациклінові антибіотики, кардіоміопатія, протеоліз, желатинази А і В, трипсиноподібні ензими, корвітин, $\alpha$-кетоглутарат.

\section{АКТИВНОСТЬ ТРИПСИНОПОДОБНЫХ ЭНЗИМОВ И ЖЕЛАТИНАЗ У КРЫС С ДОКСОРУБИЦИНОВОЙ КАРДИОМИОПАТИЕЙ}

\author{
Ю. А. Гордиенко ${ }^{1}$ Я. В. Бабеи ${ }^{2}$, \\ А. А. Кулинич ${ }^{1}$, А. И. Шевиова \\ Г. А. Ушакова
}

${ }^{1} Г У$ «Днепропетровская медицинская академия МЗ Украины»;

${ }^{2}$ Днепропетровский национальный университет имени Олеся Гончара, Украина e-mail: gordienko.ju@gmail.com

Проведено исследование активности трипсиноподобных энзимов (АТПЭ) и желатиназ А и В в плазме крови, в экстрактах сердечной мышцы, коры головного мозга и мозжечка у крыс с кардиомиопатией, вызванной антрациклиновым антибиотиком доксорубицином на фоне превентивного применения корвитина и $\alpha$-кетоглутарата. Показано, что АТПЭ достоверно увеличивается в плазме крови и экстракте коры головного мозга при доксорубициновой кардиомиопатии (ДКМП), а в экстракте сердечной мышцы и мозжечка - снижается. При ДКМП происходит достоверное повышение активности обеих желатиназ в плазме и тканевых экстрактах. Превентивное введение корвитина и $\alpha$-кетоглутарата вызывает разнонаправленные изменения активности исследуемых энзимов. Полученные данные подтверждают гипотезу о повышении активности протеолиза при применении антрациклиновых антибиотиков и свидетельствуют об избирательном влиянии $\alpha$-кетоглутарата и корвитина на АТПЭ и желатиназы.

Ключевы е с лов в а: антрациклиновые антибиотики, кардиомиопатия, протеолиз, желатиназы А и В, трипсиноподобные энзимы, корвитин, $\alpha$-кетоглутарат.

\section{References}

1. Yarovaya G. A. Bioregulating functions and pathogenetic role of proteolysis. The physiological role and biochemical mechanisms of limited proteolysis reactions. Laboratornaya Meditsina (Laboratory Medicine). 2005;(7):8190. (In Russian).

2. Rawlings N. D., Morton F. R., Kok C. Y., Kong J., Barrett A. J. MEROPS: The peptidase database. Nucleic Acids Res. 2008;(36):D320-D325.

3. Page M. J., Di Cera E. Serine peptidases: classification, structure and function. Cell Mol. Life Sci. 2008;65(7-8):1220-1236.

4. Novik A. A., Kamilova T. A., Tsygan V. N. Introduction to molecular biology of carcinogenesis. M: Geotar-Med, 2004. 224 p. (In Russian).

5. Cogni A. L., Farah E., Minicucci M. F., Azevedo P. S., Okoshi K., Matsubara B. B., Zanati S., Haggeman R., Paiva S. A., Zornoff L. A. Metalloproteinases-2 and -9 predict left ventricular remodeling after myocardial infarction. Arq. Bras. Cardiol. 2013;100(4):315-321.

6. Balabanyan V. Y., Gelperina S. E. Basic mechanisms of drug substance delivery to the brain using polymeric nanoparticles. Farmakokinetika $i$ farmakdinamika (Pharmacokinetics and pharmacodynamics). 2012;5(2):3-9. (In Russian).

7. Kapelko V. I., Popovich M. Metabolic and functional basis of experimental cardiomyopathies. Kishinev: Shtiintsa, 1990. P. 6-56. (In Russian).

8. Veremeenko K. N., Goloborod'ko O. P., Kizim A. I. Proteolysis in normal and pathological conditions. Kiev: Zdorov'ia (Health), 1988. 200 p. (In Russian).

9. Pat. 83196 UA, ICP G 01 N33/49 Method of determining gelatinases blood plasma. Shevtsova A. I., Gordienko Yu. A., Shaulska O. E., Skoromna A. S. Publ. 27.08.2013, Bul. N 16. (In Ukrainian). 
10. Bradford M. M. A rapid and sensitive method for the quantification of microgramme quantities of protein utilizing the principle of protein-dye binding. Anal. Biochem. - 1976;72(1-2):248-254.

11. Shevtsova A. I., Zharikov N. Y., Gordienko Yu. A. Experimental study of the corvitin effect under conditions of doxorubicin-induced cardiomyopathy in rats. Mat. of theoretical and practical conference "Actual problems of medicine." Grodno, Belarus, 2013. P. 386-388. (In Russian).

12. Kim S. H., Lim K. M., Noh J. Y., Kim K., Kang S., Chang Y. K., Shin S., Chung J. H. Doxorubicininduced platelet procoagulant activities: an important clue for chemotherapy-associated thrombosis. Toxicol. Sci. 2011;124(1):215-224.

13. Kennedy S., Wu J., Wadsworth R. M., Lawrence C. E., Maffia P. Mast cells and vascular diseases. Pharmacol. Ther. 2013;138(1)53-65.

14. Ratcliffe P. J. Oxygen sensing and hypoxia signalling pathways in animals: the implications of physiology for cancer. J. Physiol. 2013;591(Pt 8):2027-2042.

15. Tulsawani R., Bhattacharya R. Effect of alphaketoglutarate on cyanide-induced biochemical alterations in rat brain and liver. Biomed. Environ. Sci. 2006;19(1):61-66.

16. Kovalenko T. N., Ushakova G. A., Osadchenko I., Skibo G. G., Pierzynowski S. G. The neuroprotective effect of 2-oxoglutarate in the experimental ischemia of hippocampus. J. Physiol. Pharmacol. 2011;62(2):239-246.

17. Mukhopadhyay P., Rajesh M., Batkai S., Kashiwaya Y., Hasko G., Liaudet L., Szabo C., Pacher P. Role of superoxide, nitric oxide, and peroxynitrite in doxorubicin-induced cell death in vivo and in vitro. Am. J. Physiol. Heart Circ. Physiol. 2009;296(5):1466-1483.

18. Kandasamy A. D., Chow A. K., Ali M. A., Schulz R. Matrix metalloproteinase-2 and myocardial oxidative stress injury: beyond the matrix. Cardiovasc. Res. 2010;85(3):413-423.
19. Lakhanpal P., Rai D. K. Role of quercetin in cardiovascular diseases. Internet J. Med. Update. 2008;3(1):31-49

20. Wang L., Cheng X., Li H., Qiu F., Yang N., Wang B., Lu H., Wu H., Shen Y., Wang Y., Jing H. Quercetin reduces oxidative stress and inhibits activation of c Jun $\mathrm{N}$ terminal kinase/ activator protein 1 signaling in an experimental mouse model of abdominal aortic aneurysm. Mol. Med. Rep. 2014;9(2):435-442.

21. Frontczak-Baniewicz M., Walski M., Madejska G., Sulejczak D. MMP2 and MMP9 in immature endothelial cells following surgical injury of rat cerebral cortex a preliminary study. Folia Neuropathol. 2009;47(4):338-346.

22. Lopes M. A., Meisel A., Carvalho F. D., Bastos M. Neuronal nitric oxide synthase is a key factor in doxorubicin-induced toxicity to rat-isolated cortical neuron. Neurotox. Res. 2011;19(1):14-22.

23. Park J., Zhang Y., Vykhodtseva N., Jolesz F. A., McDannold N. J. The kinetics of blood brain barrier permeability and targeted doxorubicin delivery into brain induced by focused ultrasound. J. Control Release. 2012;162(1):134142.

24. Candelario-Jalil E., Thompson J., TaheriS., Grossetete M., Adair J. C., Edmonds E., Prestopnik J., Wills J., Rosenberg G.A. Metalloproteinases are associated with increased blood-brain barrier opening in vascular cognitive impairment. Stroke. 2011;42(5):1345-1350.

25. Cho J. Y., Kim I. S., Jang Y. H., Kim A. R., Lee S. R. Protective effect of quercetin, a natural flavonoid against neuronal damage after transient global cerebral ischemia. Neurosci. Lett. 2006;404(3):330-335.

26. Yang Y., Bai L., Li X., Xiong J., Xu P., Guo C., Xue M. Transport of active flavonoids, based on cytotoxicity and lipophilicity: An evaluation using the blood-brain barrier cell and Caco-2 cell models. Toxicol. in Vitro. 2014;28(3):388396. 